\title{
Analysis of Aquaponic-Recirculation Aquaculture System (A - Ras) Application in the Catfish (Clarias gariepinus) Aquaculture in Indonesia
}

\author{
Arning Wilujeng Ekawati ${ }^{1}$, Siti Mariyah Ulfa ${ }^{2}$, Citra Satrya Utama Dewi ${ }^{3}$, Abdul Aziz \\ Amin $^{4}$, Lutfi Ni'matus Salamah ${ }^{4}$, Adi Tiya Yanuar ${ }^{4}$, Andi Kurniawan ${ }^{5, *}$ (i)
}

\author{
${ }^{1}$ University of Brawijaya, Department of Aquaculture, Jalan Veteran, Malang, Indonesia, 65145. \\ ${ }^{2}$ University of Brawijaya, Department of Chemistry, Jalan Veteran, Malang, Indonesia, 65145. \\ ${ }^{3}$ University of Brawijaya, Department of Marine Science, Jalan Veteran, Malang, Indonesia, 65145. \\ ${ }^{4}$ University of Brawijaya, Coastal and Marine Research Centre, Jalan Veteran, Malang, Indonesia, 65145. \\ ${ }^{5}$ University of Brawijaya, Department of Aquatic Resources Management, Jalan Veteran, Malang, Indonesia, 65145.
}

How to cite

Ekawati, A.W., Ulfa, S.M., Dewi, C.S.U., Amin, A.A., Salamah, L.N., Yanuar, A.T., Kurniawan, A. (2021). Analysis of AquaponicRecirculation Aquaculture System (A - Ras) Application in the Catfish (Clarias gariepinus) Aquaculture in Indonesia. Aquaculture Studies, 21, 93-100. http://doi.org/10.4194/2618-6381-v21_3_01

\section{Article History}

Received 26 October 2020

Accepted 01 February 2021

First Online 11 February 2021

\section{Corresponding Author \\ Tel.: +6281283381100 \\ E-mail: andi_k@ub.ac.id}

\section{Keywords}

Sustainable aquaculture

Water quality

Aquaculture waste

Aquaculture technology

\begin{abstract}
Water quality and waste management are significant problems for aquaculture in Indonesia, including catfish (Clarias gariepinus) aquaculture. A combination of Aquaponics Systems and Recirculating Aquaculture Systems (A-RAS) has been developed to address this problem. This study analyzed A-RAS application for catfish (Clarias gariepinus) aquaculture by comparing water quality and production indicators between A-RAS and conventional methods. The results show that temperature, $\mathrm{pH}$, dissolved oxygen, total organic matter, ammonia, nitrate and nitrite in A-RAS technology were $28.0-30.0^{\circ} \mathrm{C}, 6.5-7.9,3.8-7.8 \mathrm{mg} / \mathrm{L}, 18.54-24.97 \mathrm{mg} / \mathrm{L}, 0.12-0.28$ $\mathrm{mg} / \mathrm{L}, \quad 0.12-0.13 \mathrm{mg} / \mathrm{L}$, and $0.04-0.13 \mathrm{mg} / \mathrm{L}$, respectively. Survival Rate, Feed Conversion Ratio, and harvest in A-RAS application were $85.5 \%, 1.1$, and $26 \mathrm{~kg} / \mathrm{m}^{3}$, respectively. A-RAS technology can maintain water quality to be reused in cultivation and increase yields by about $13 \%$. Besides, water spinach can be an additional income for farmers.
\end{abstract}

\section{Introduction}

Catfish (Clarias gariepinus) is widely cultivated in various regions in Indonesia. Catfish (C. gariepinus) aquaculture faces obstacles related to water quality and waste management (Henriksson et al., 2017; Tran et al., 2017). Ineffective water management has made many catfish farmers change their pond water frequently (Panase et al., 2018; Ekasari et al., 2016). This problem has led to an increase in water use for catfish cultivation, making it difficult for catfish farming to develop in areas facing water availability problems. Hence, the limitation of decent water restrains the development of aquaculture in Indonesia.
Along with frequent water changes during the aquaculture process, catfish farmers usually dispose of waste directly into the environment. The waste often causes environmental pollution because it is not treated before disposal. Therefore, the development of aquaculture innovation is fundamentally essential to develop catfish farming in Indonesia into sustainable aquaculture practices.

Various technologies have been developed to solve the water quality and waste management problems in aquaculture (Yi et al., 2018; Pouil et al., 2018; Yamazaki et al., 2018). One of the innovations is the combination of aquaponics systems and recirculation aquaculture systems. The Aquaponics - Recirculation Aquaculture 
System (A-RAS) is being developed by the Coastal and Marine Research Center of the University of Brawijaya. The technology's basic principle is to integrate the Recirculation Aquaculture System and the Aquaponics system, which serve as a biological filter system to maintain the water quality in the aquaculture (MaigualEnriquez et al., 2002; Azaria \& Rijn 2018; Badiola et al., 2018). The A-RAS is developed to maintain the water quality so that it can be reused. The technology will decrease the waste discharge from aquaculture production.

This study aims to analyze the application of A-RAS technology in the catfish ( $C$. gariepinus) aquaculture. The indicator to evaluate the A-RAS technology is water qualities (i.e., temperature, $\mathrm{pH}$, dissolved oxygen, total organic matter, ammonia, nitrate, and nitrite), and production indicators (i.e., survival rate, food conversion ratio, and harvest). This study indicates that the A-RAS can increase the effectiveness and efficiency of the catfish ( $C$. gariepinus) aquaculture. The application of A-RAS makes water quality can be continuously maintained to fulfill the catfish's ideal requirement. Moreover, the A-RAS application increases the quality of the production indicators and provides water spinach as an additional income to the farmers.

\section{Materials and Methods}

\section{A-RAS construction}

A-RAS integrates water spinach aquaponics and recirculation aquaculture system (Figure 1). The aquaponics acts as a bio filter to reduce aquaculture waste. A-RAS also operates swirl and bio ball filters to maintain water quality during cultivation. The feeds were given two times a day with a dose of 5-6\% of fish weight. Water replacement in ponds (about $30 \%$ of the water volume) was carried out when $\mathrm{DO}$ and water $\mathrm{pH}$ exceed the maximum standard for catfish life. The control of this experiment is a pond cultivated conventionally. In this control pond, feeding was given using the same method as the A-RAS pond, but water changes were carried out when the DO and the water's $\mathrm{pH}$ had passed the ideal quality standard for catfish farming. Therefore, in control ponds, water changes were carried out more frequently than in A-RAS ponds.

The pond construction uses an iron frame with a High-Density Polyethylene (HDPE) membrane. The diameter of the pool is $3 \mathrm{~m}$ with a pool height of $1.25 \mathrm{~m}$. The pools were filled with water up to a height of $0.9 \mathrm{~m}$. The stocking density used was 2000 fish/pond using fingerlings ( $\pm 2.1 \mathrm{~g} /$ fish). Fish were harvested after 60 days of cultivation with an average size of $100 \mathrm{~g} / \mathrm{fish}$.

Water spinach was sown until it was approximately $10 \mathrm{~cm}$ in size before being used in A-RAS construction. The media used to grow water spinach in A-RAS was Rockwool media placed in a plastic tube $(5 \mathrm{~cm}$ in diameter and $7 \mathrm{~cm}$ high). Water spinach is harvested every 30 days (average stem length is $30 \mathrm{~cm}$ ) and replaced by new water spinach $(10 \mathrm{~cm})$.

The construction for growing water spinach is a PVC pipe with a diameter of $75 \mathrm{~mm}$. This PVC pipe is perforated with a hole diameter of $5 \mathrm{~cm}$ with a distance between holes is $25 \mathrm{~cm}$. This hole is used to insert the

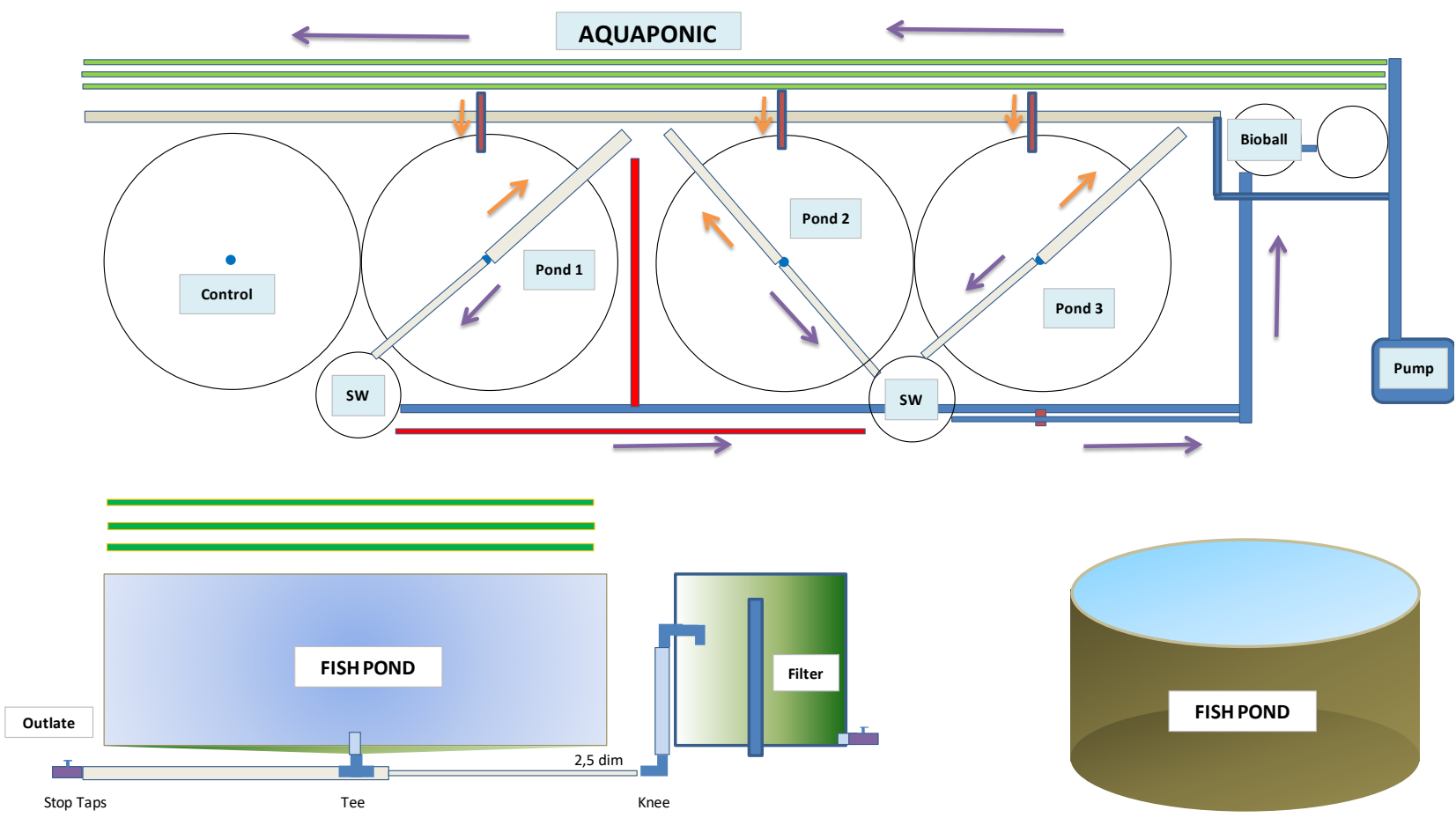

Figure 1. Design of the A-RAS technology for the catfish (C. gariepinus) aquaculture. SW is a swirl filter, Bio ball is the filter using bio balls as a substrate for microbes, and the arrows are the water flow direction. 
plastic tube used to grow the water spinach. The aquaponics construction in A-RAS consists of 7 PVC pipes with a length of $15 \mathrm{~m}$ each.

\section{Water quality measurement}

Temperature, $\mathrm{pH}$, dissolved oxygen, total organic matter, ammonia, nitrate and nitrite were measured in this study. Temperature, $\mathrm{pH}$ and dissolved oxygen were measured daily using a Digital Integrated thermometer, $\mathrm{pH}$ meter and DO meter. Total organic matter, ammonia, nitrate and nitrite were measured in $0,15,30$, 45 , and 60 days of culture. Water qualities in the 3 ponds of A-RAS construction were measured and the average values were used. In the case of control ponds, the measurements were carried out in 3 replications.

Temperature, $\mathrm{pH}$, dissolved oxygen, total organic matter, ammonia, nitrate and nitrite were measured in this study. Temperature, $\mathrm{pH}$ and dissolved oxygen were measured daily using a Digital Integrated thermometer, $\mathrm{pH}$ meter and DO meter. Total organic matter, ammonia, nitrate and nitrite were measured in $0,15,30$, 45 , and 60 days of culture. Water qualities in the 3 ponds of A-RAS construction were measured and the average values were used. In the case of control ponds, the measurements were carried out in 3 replications. Data analysis to determine the effect of A-RAS application on water quality during catfish farming was carried out through t-test statistical analysis using Minitab v.17.

\section{Aquaculture production indicator}

The aquaculture production indicator analyzed in this study were Survival Rate, Food Conversion Ratio, and Harvest Production. The Survival Rate was calculated based on the equation (1):

$$
\mathrm{SR}=\frac{\mathrm{Nt}}{\mathrm{N} 0} \times 100 \%
$$

$\mathrm{SR}$ is survival rate (\%), $\mathrm{Nt}$ is the number of fish that live at the end of the cultivation period, and NO is the number of fish that live at the beginning of the cultivation period. Food conversion ratio calculated based on the equation (2);

$$
F C R=\frac{\text { Feed given }}{\text { Weight gain }}
$$

FCR is the food conversion ratio, which is defined as the mass of the input divided by the output (mass of feed per mass of harvested fish). The feed given is the given feed (kg), while Weight gain is the bodyweight of harvested fish $(\mathrm{kg})$.

\section{Results and Discussion}

This study analyzes the application of the Aquaponics - Recirculation Aquaculture Systems (ARAS) in the catfish (C. gariepinus) aquaculture. The main indicators in the analysis are water quality and aquaculture product parameters. The detailed analysis is described below.

\section{Water quality during fish cultivation}

A-RAS was designed to maintain the water quality during fish cultivation. Hence, waste discharge and water exchange can be minimized because water can be reused during the cultivation process. In order to analyze the achievement of this aim, the water qualities (i.e., temperature, $\mathrm{pH}$, dissolved oxygen, total organic matter, ammonia, nitrate and nitrite) during catfish

\begin{tabular}{|c|c|c|c|c|c|c|}
\hline Parameters & $\mathbf{N}$ & Mean & StDev & SE Mean & Difference & P-value \\
\hline \multicolumn{7}{|l|}{ Temperature } \\
\hline A-Ras & 61 & 28.831 & 0.416 & 0.053 & \multirow{2}{*}{-0.0628} & \multirow{2}{*}{0.473} \\
\hline $\begin{array}{l}\text { Control } \\
p H\end{array}$ & 61 & 28.893 & 0.541 & 0.069 & & \\
\hline A-Ras & 61 & 7.594 & 0.182 & 0.023 & \multirow{2}{*}{-0.0107} & \multirow{2}{*}{0.738} \\
\hline Control & 61 & 7.604 & 0.169 & 0.022 & & \\
\hline \multicolumn{7}{|l|}{ DO } \\
\hline A-Ras & 61 & 5.070 & 1.110 & 0.140 & \multirow{2}{*}{0.338} & \multirow{2}{*}{0.151} \\
\hline Control & 61 & 4.730 & 1.450 & 0.190 & & \\
\hline \multicolumn{7}{|l|}{ TOM } \\
\hline A-Ras & 5 & 21.510 & 3.100 & 1.400 & \multirow{3}{*}{-20.04} & \multirow{2}{*}{$0.065^{*}$} \\
\hline Control & 5 & 41.500 & 17.400 & 7.800 & & \\
\hline \multicolumn{6}{|l|}{ Ammonia } & \\
\hline A-Ras & 5 & 0.214 & 0.073 & 0.033 & \multirow{2}{*}{-0.695} & \multirow{2}{*}{$0.081 *$} \\
\hline Control & 5 & 0.909 & 0.666 & 0.300 & & \\
\hline \multicolumn{7}{|l|}{ Nitrate } \\
\hline A-Ras & 5 & 0.137 & 0.015 & 0.007 & \multirow{3}{*}{-0.501} & \multirow{2}{*}{$0.096 *$} \\
\hline Control & 5 & 0.638 & 0.515 & 0.230 & & \\
\hline \multicolumn{6}{|l|}{ Nitrite } & \\
\hline A-Ras & 5 & 0.097 & 0.036 & 0.016 & \multirow{2}{*}{-0.0867} & \multirow{2}{*}{$0.098 *$} \\
\hline Control & 5 & 0.184 & 0.089 & 0.040 & & \\
\hline
\end{tabular}

Table 1. Statistical analysis results 

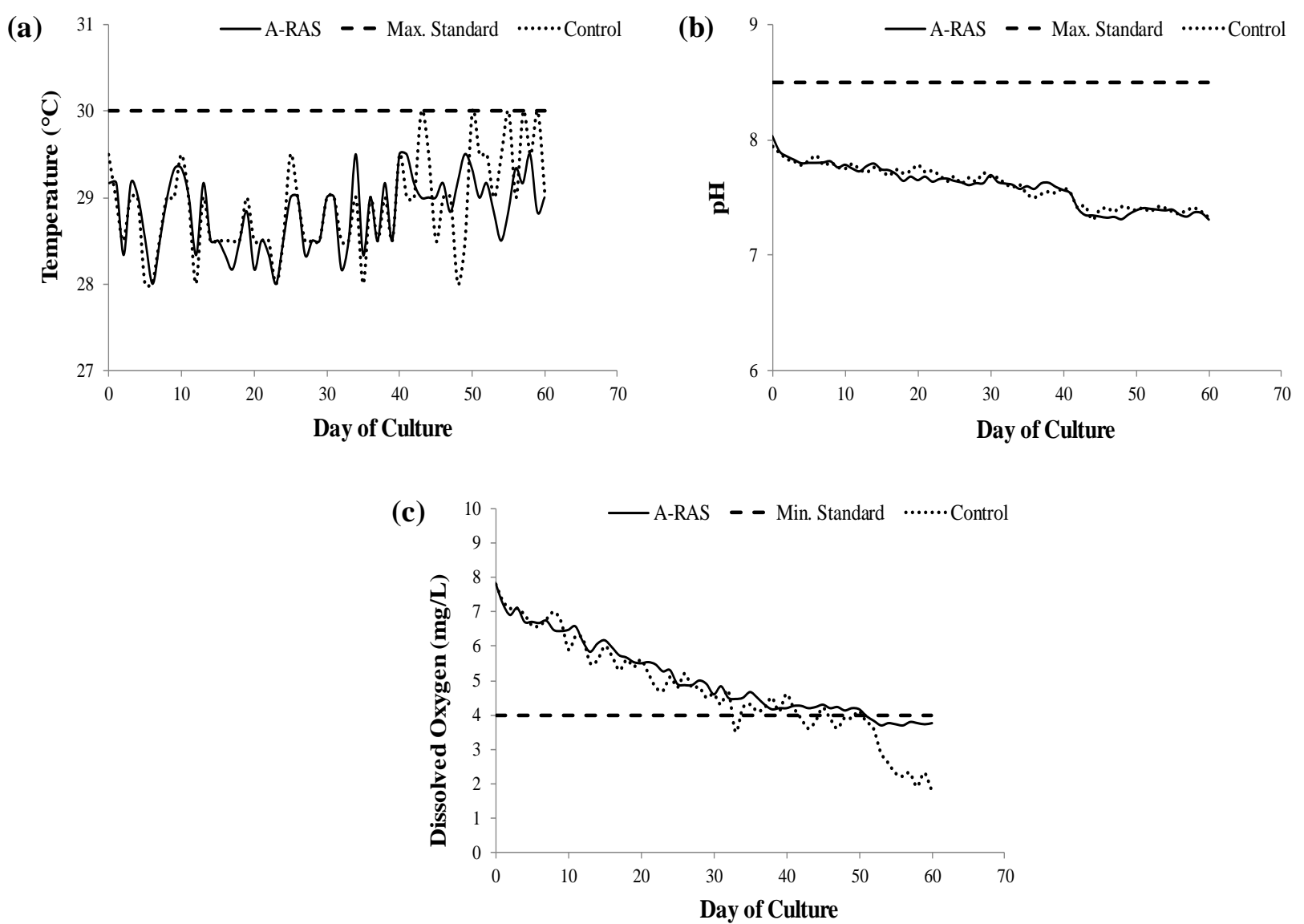

Figure 2. Temperature (a), pH (b) and dissolved oxygen (c) during catfish (C. gariepinus) cultivation.

(C. gariepinus) aquaculture using the A-RAS technology were compared to those of the conventional methods as the control of the experiments. Temperature, $\mathrm{pH}$, and dissolved oxygen in the A-RAS ponds were daily measured and the results were compared to those of the control (the conventional method without A-RAS) (Figure 2). The results of data analysis using statistical analysis are shown in Table 1.

The water temperature in the catfish (C. gariepinus) aquaculture using the A-RAS technology ranged between 28.0 and $30.0^{\circ} \mathrm{C}$. This temperature is relatively not different from the temperature of the control (conventional method) ( $p$-value $=0.473$ ). The maximum standard of temperature for the catfish (C. gariepinus) aquaculture is $25-30^{\circ} \mathrm{C}$ (Indonesian National Standard, 2002). Thus, both the aquaculture system can provide a suitable temperature for the catfish (C.gariepinus). The dynamic temperature changes in this study can be caused due to the temperature dynamics of the environment around the ponds (Sabaori et al., 2016; Senff et al., 2018). The pH of the water in applying A-RAS technology ranged from 6.5-7.9. These values are relatively the same as the case of the control pond ( $p$-value $=0.738$ ). The ideal $\mathrm{pH}$ to support catfish (C. gariepinus) is 6.5-8.5 (Indonesian National Standard, 2002). It seems that A-RAS technology and the conventional method can fulfill the $\mathrm{pH}$ requirement.
Dissolved oxygen (DO) in the catfish aquaculture using the A-RAS technology ranged from $3.8 \mathrm{mg} / \mathrm{L}$ until $7.8 \mathrm{mg} / \mathrm{L}$, while the dissolved oxygen in control ranged from $1.8 \mathrm{mg} / \mathrm{L}$ until $7.8 \mathrm{mg} / \mathrm{L}$. The minimum ideal of DO for the catfish aquaculture is $4 \mathrm{mg} / \mathrm{L}$ (Indonesian National Standard, 2002). The A-RAS technology can maintain the $D O$ in the ideal value until about 50 days of culture, while the conventional method can provide until 40 days of culture. After 50 days of culture, the DO in the A-RAS technology slightly decreased until 3.8 $\mathrm{mg} / \mathrm{L}$ in 60 days. The DO in control continuously decreases until it reaches $1.8 \mathrm{mg} / \mathrm{L}$ in 60 days of culture. Hence, A-RAS technology can provide a better value of DO than conventional technology; however, the difference was not statistically significant ( $p$ value $=0.151$ ). The decrease of the $\mathrm{DO}$ can be caused by an increase in the amount of leftover feed and metabolic waste and an increase in oxygen consumption along with fish growth (Li et al., 2019; Ho et al., 2019; Hu et al., 2015). The results of this study indicate that even though the application of A-RAS the water change is carried out only once, the water quality (i.e., temperature, $\mathrm{pH}$ and $\mathrm{DO}$ ) in the A-RAS ponds is not much different, even slightly better than the conventional method of replacing water up to 7 times.

The primary problem related to aquaculture's water quality is the increasing concentration of organic matter and nutrients along with the day of culture, 
mainly due to the leftover feed and metabolic waste. Thus, the success of the A-RAS application is analyzed from the ability of the system to maintain water quality. The A-RAS technology is designed to maintain the water's quality to fulfill the standard threshold of catfish (C. gariepinus) aquaculture. In this study, the total organic matter (Figure 3a), ammonia (Figure 3b), nitrate (Figure 3c) and nitrite (Figure 3d) during catfish cultivation were measured.

Total organic matter (TOM) in the ponds with the A-RAS technology ranged between 18.54-24.97 mg/L while the control ranged between $18.21-61.34 \mathrm{mg} / \mathrm{L}$. The ideal value of the TOM in catfish aquaculture is less than $30 \mathrm{mg} / \mathrm{L}$ (Indonesian National Standard, 2002). ARAS application can significantly affect the TOM content in the pond ( $p$-value $=0.065$ ) and produce a better environment than the conventional method. In the conventional method, the value of total organic matter continuously increased to exceed the ideal limit on the 15th day of culture. The biological filter provided through the aquaponics system in A-RAS seems to filter and utilize the remaining organic matter from the fish cultivation process (Froehlich et al., 2017; Ahmed et al., 2019; Brooks \& Conkle, 2019; Kurniawan \& Yamamoto, 2019).

The concentrations of ammonia, nitrate, and nitrite in the ponds using the A-RAS technology ranged between $0.12-0.28 \mathrm{mg} / \mathrm{L}, 0.12-0.13 \mathrm{mg} / \mathrm{L}$, and $0.04-0.13$ $\mathrm{mg} / \mathrm{L}$, respectively. In the conventional method, the concentration of ammonia, nitrate, and nitrite was 0.27 $1.81 \mathrm{mg} / \mathrm{L}, 0.12-1.36$, and 0.05-2.95 mg/L, respectively. The maximum ideal concentration of ammonia, nitrate, and nitrite for catfish aquaculture are $1 \mathrm{mg} / \mathrm{L}, 0.15 \mathrm{mg} / \mathrm{L}$, and $1 \mathrm{mg} / \mathrm{L}$, respectively (Indonesian National Standard, 2002., Granada et al., 2018; Gorito et al., 2018; Groenveld et al., 2019). Application of the A-RAS can significantly impact nutrient ion concentrations in pond water compared to conventional methods ( $p$-values for ammonia, nitrate and nitrite are 0.081, 0.096 and 0.098, respectively). The concentrations of ammonia and

Table 2. Production indicators of the catfish aquaculture

\begin{tabular}{lcc}
\hline Parameters & A-RAS & Control \\
\hline Survival rate (\%) & 85.5 & 70 \\
Food Conversion Ratio & 1.1 & 1.7 \\
Harvest $\left(\mathrm{kg} / \mathrm{m}^{3}\right)$ & 26 & 23 \\
Water disposal time (times/cycle) & 1 & 7 \\
Additional product & Water spinach \\
\hline
\end{tabular}

a)

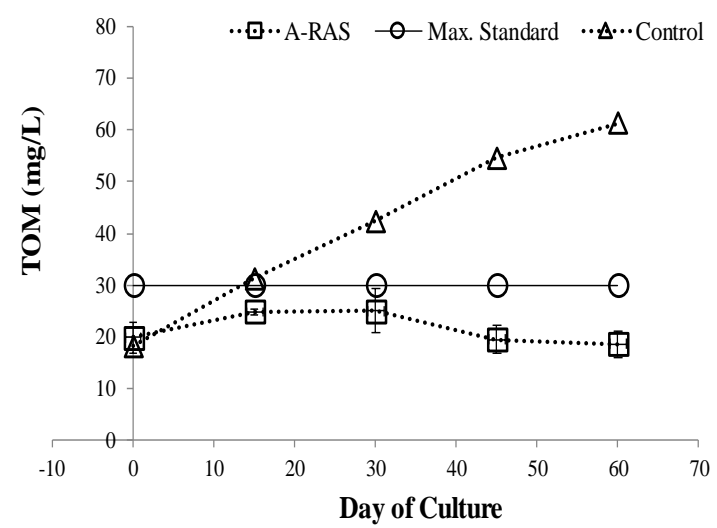

c)

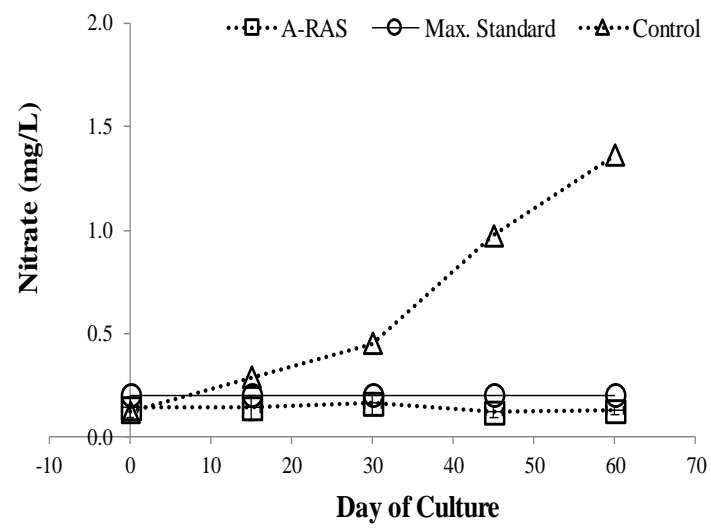

b)

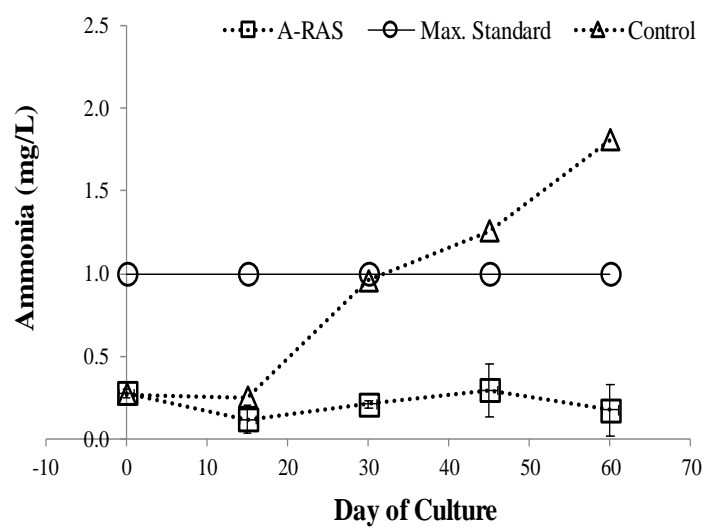

d)

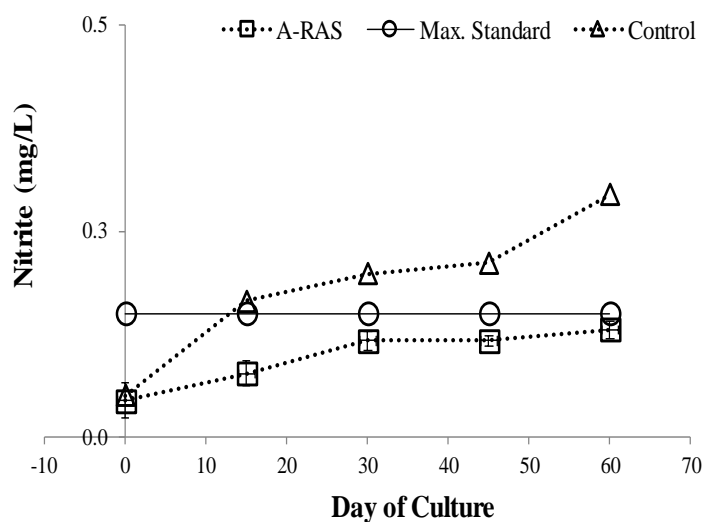

Figure 3. Total organic matter (a), Ammonia (b), Nitrate (c), and nitrite (d) during catfish (C. gariepinus) cultivation. 
nitrate in the ponds using the A-RAS technology were relatively stable from the beginning until the end of cultivation. On the other hand, the concentration of ammonia and nitrate in the conventional method continuously increases until it exceeds the ideal concentration. The nitrite concentration in the ponds using the A-RAS technology is slightly increased and still in the ideal range for catfish, whereas the conventional method continuously increases until it exceeds the ideal concentration for the catfish aquaculture. These results suggested that the A-RAS technology application can always maintain the water quality in the ideal range for the catfish aquaculture.

The cultivation system built-in A-RAS provides a water recirculation system by utilizing a swirl filter and bio ball filter to clean the pond's aquaculture waste. After this filtering process, the water flows into the aquaponics system, which uses the water spinach as a biological filter. Water spinach in aquaponics construction plays a role in absorbing excess nutrient ions in water. Therefore, A-RAS can maintain the quality of pond water so that it continues to be used in catfish farming.

\section{Aquaculture production indicator}

In order to analyze the application of A-RAS technology in catfish (C. gariepinus) aquaculture, the production indicators of the A-RAS were compared to those of the conventional method (control) (Table 2). The results in Table 2 suggest that applying the A-RAS technology can improve all aquaculture production indicators compared to those of the control (conventional method). A-RAS technology can increase the survival rate and harvest while decrease food conversion ratio and water disposal.

This study suggests that A-RAS can provide better aquaculture production than the conventional method. The application of the technology can decrease waste disposal because the water quality can be maintained in the ideal range for catfish aquaculture, and thus, can be reused. Moreover, applying A-RAS technology may also produce water spinach as an additional product for the fish farmers every 30 days. This study suggested that ARAS technology can improve catfish aquaculture production while maintaining environmental sustainability.

\section{Conclusion}

This study analyzes the application of the Aquaponics - Recirculation Aquaculture System (A-RAS) in the catfish ( $C$. gariepinus) aquaculture. The results show that the values of temperature, $\mathrm{pH}$, dissolved oxygen, total organic matter, ammonia, nitrate and nitrite ranged between $28.0-30.0^{\circ} \mathrm{C}, 6.5-7.9,3.8-7.8$ $\mathrm{mg} / \mathrm{L}, \quad 18.54-24.97 \mathrm{mg} / \mathrm{L}, \quad 0.12-0.28 \mathrm{mg} / \mathrm{L}, \quad 0.12-0.13$ $\mathrm{mg} / \mathrm{L}$, and $0.04-0.13 \mathrm{mg} / \mathrm{L}$, respectively. The survival rate values, food conversion ratio and harvest are $85.5 \%$,
1.1 , and $26 \mathrm{~kg} / \mathrm{m}^{3}$, respectively. This study suggests that the A-RAS technology can maintain water quality in the ideal range for the catfish aquaculture, and thus, can be reused in the aquaculture. The application of the A-RAS can increase the harvested product by about $13 \%$. Moreover, the water spinach used as a biological filter in the aquaponics systems can increase the farmers' income. According to the result of this study, applying ARAS technology may improve catfish aquaculture and support sustainable aquaculture development in Indonesia.

\section{Ethical statements}

All applicable international, national, and/or institutional guidelines for the care and use of animals were followed.

\section{Funding Information}

This research funding is supported by the Regional Superior Product Development Grant Program, Ministry of Research and Technology, Republic of Indonesia.

\section{Author Contribution}

Conceptualization: Arning Wilujeng Ekawati, Siti Mariyah Ulfa, Citra Satrya Utama Dewi, Abdul Aziz Amin, Lutfi Ni'matus Salamah, Adi Tiya Yanuar, Andi Kurniawan

Methodology: Arning Wilujeng Ekawati, Siti Mariyah Ulfa, Citra Satrya Utama Dewi, Abdul Aziz Amin, Lutfi Ni'matus Salamah, Adi Tiya Yanuar, Andi Kurniawan

Software: Arning Wilujeng Ekawati, Siti Mariyah Ulfa, Citra Satrya Utama Dewi, Abdul Aziz Amin, Lutfi Ni'matus Salamah, Adi Tiya Yanuar, Andi Kurniawan

Validation: Arning Wilujeng Ekawati, Siti Mariyah Ulfa, Citra Satrya Utama Dewi, Abdul Aziz Amin, Lutfi Ni'matus Salamah, Adi Tiya Yanuar, Andi Kurniawan

Formal analysis: Arning Wilujeng Ekawati, Siti Mariyah Ulfa, Citra Satrya Utama Dewi, Abdul Aziz Amin, Lutfi Ni'matus Salamah, Adi Tiya Yanuar, Andi Kurniawan Investigation: Arning Wilujeng Ekawati, Siti Mariyah Ulfa, Citra Satrya Utama Dewi, Abdul Aziz Amin, Lutfi Ni'matus Salamah, Adi Tiya Yanuar, Andi Kurniawan

Resources: Arning Wilujeng Ekawati, Siti Mariyah Ulfa, Citra Satrya Utama Dewi, Abdul Aziz Amin, Lutfi Ni'matus Salamah, Adi Tiya Yanuar, Andi Kurniawan

Data curation: Arning Wilujeng Ekawati, Siti Mariyah Ulfa, Citra Satrya Utama Dewi, Abdul Aziz Amin, Lutfi Ni'matus Salamah, Adi Tiya Yanuar, Andi Kurniawan

Writing - Original Draft: Arning Wilujeng Ekawati, Siti Mariyah Ulfa, Citra Satrya Utama Dewi, Abdul Aziz Amin, Lutfi Ni'matus Salamah, Adi Tiya Yanuar, Andi Kurniawan

Writing - Review \& Editing: Arning Wilujeng Ekawati, Siti Mariyah Ulfa, Citra Satrya Utama Dewi, Abdul Aziz Amin, Lutfi Ni'matus Salamah, Adi Tiya Yanuar, Andi Kurniawan 
Visualization: Arning Wilujeng Ekawati, Siti Mariyah Ulfa, Citra Satrya Utama Dewi, Abdul Aziz Amin, Lutfi Ni'matus Salamah, Adi Tiya Yanuar, Andi Kurniawan

Supervision: Arning Wilujeng Ekawati, Andi Kurniawan

Project administration: Arning Wilujeng Ekawati, Siti Mariyah Ulfa, Citra Satrya Utama Dewi, Andi Kurniawan

Funding acquisition: Arning Wilujeng Ekawati, Siti Mariyah Ulfa, Citra Satrya Utama Dewi, Andi Kurniawan

\section{Conflict of Intrest}

The authors declare that they have no conflicts of interest.

\section{Acknowledgment}

This research is supported by the Directorate for Research and Community Service, Directorate General of Strengthening Research and Development, Ministry of Research and Technology of the Republic of Indonesia. The authors thank the Coastal and Marine Research Centre of the University of Brawijaya for the facilities provided for this study.

\section{References}

Ahmed, N., \& Thompson, S. (2019). The blue dimension of aquaculture: a global synthesis. Science of The Total Environment, Netherlands, 652(1), 851-861. https://doi.org/10.1016/j.scitotenv.2018.10.163

Azaria, A., \& Rijn, J. V. (2018), Off-flavor compounds in recirculating aquaculture systems (RAS): production and removal processes. Aquacultural Engineering, USA, 83(1), 57-64.

https://doi.org/10.1016/j.aquaeng.2018.09.004

Badiola, M., Basurko, O.C., Piedrahita, R., Hundley, P., \& Mendiola, D., (2018). Energy use in recirculating aquaculture system (RAS): a review. Aquacultural Engineering, USA, 81(1), 57-70. https://doi.org/10.1016/j.aquaeng.2018.03.003

Brooks, B. W., \& Conkle, J. L. (2019). Commentary: perspective on aquaculture, urbanization and water quality. Comparative Biochemistry and Physiology Part C: Toxicology \& Pharmacology, Netherlands, 217(1), 1-4. https://doi.org/10.1016/j.cbpc.2018.11.014

Ekasari, J., Suprayudi, M. A., Wiyoto, W., Hazanah, R. F., Lenggara, G. S., Sulistiani, R., Alkahfi, M., \& Zairin, M. (2016). Biofloc technology application in African catfish fingerling production: The effects on the reproductive performance of broodstock and the quality of eggs and larvae. Aquaculture. Netherlands, 464(1), 349-356. https://doi.org/10.1016/j.aquaculture.2016.07.013

Froehlich, H. E., Gentry, R. R., \& Halpem, B. S. (2017). Conservation aquaculture: shifting the narrative and paradigm of aquaculture's role in resource management. Biological Conservation, Netherlands, 215(1), 162-168. https://doi.org/10.1016/j.biocon.2017.09.012

Gorito, A. M., Ribeiro, A. R., Gomes, C. R., Marisa, C., Almedia, R., \& Silva, A. M. T. (2018). Constructed wetland microcosms for the removal of organic micropollutants from freshwater aquaculture effluents. Science of The Total Environment, Netherlands, 644(1), 1171-1180. https://doi.org/10.1016/j.scitotenv.2018.06.371

Granada, L., Lopes, S., Novais, S. C., \& Lemos, M. F. L. (2018). Modelling integrated multi-trophic aquaculture: optimizing a three trophic level system. Aquaculture, Netherlands, 495(1), 90-97.

https://doi.org/10.1016/j.aquaculture.2018.05.029

Groenveld, T., Kohn, Y. Y., Gross, A., \& Lazarovitch, N. (2019). Optimization of nitrogen use efficiency by means of fertigation management in an integrated aquacultureagriculture system. Cleaner Production, 212(1), 401408. https://doi.org/10.1016/j.jclepro.2018.12.031

Henriksson, P. J. G., Tran, N., Mohan, C. V., Chan, C. Y., Rodriguez, U.-P., Suri, S., Mateos, L. D., Utomo, N. B. P., Hall, S., \& Phillips, M. J. (2017). Indonesian aquaculture futures - Evaluating environmental and socioeconomic potentials and limitations. J. Cleaner Prod. Netherlands, 162(1), 1482-1490. https://doi.org/10.1016/j.jclepro.2017.06.133

Ho, L. T., Alvarado, A., Larriva, J., Pompeu, C., \& Goethals, P. (2019). An integrated mechanistic modelling of a facultative pond: parameter estimation and uncertainty analysis. Water Research, USA, 151(1), 170-182. https://doi.org/10.1016/j.watres.2018.12.018

Hu, Z., Lee, J. W., Chandran, K., Kim, S., Brotto, A. C., \& Khanal, S. K. (2015). Effect of plant species on nitrogen recovery in aquaponics. Bioresource Technology, Netherlands, 188(1), 92-98.

https://doi.org/10.1016/j.biortech.2015.01.013

Indonesian National Standard. (2002). SNI 01-6484,5:2002 Ikan lele dumbo (Clarias sp.)

Kurniawan, A \& Yamamoto, T. (2019). Accumulation of $\mathrm{NH}_{4}{ }^{+}$ and $\mathrm{NO}_{3}{ }^{-}$inside Biofilms of Natural Microbial Consortia: Implication on Nutrients Seasonal Dynamic in Aquatic Ecosystems. International Journal of Microbiology, United Kingdom, 6473690. https://doi.org/10.1155/2019/6473690

Li, F., Sun, Z., Qi, H., Zhou, X., Xu, C., Wu, D., Fang, F., Feng, J., \& Zhang, N. (2019). Effects of rice-fish co-culture on oxygen consumption in intensive aquaculture pond. Rice Science, China, 26(1), 50-59. https://doi.org/10.1016/j.rsci.2018.12.004

Maigual-Enriquez, Y. A., Maia, A. A. D., Guerrero-Romero, C. L., Matsumoto, T., Rangel, E. C., \& de Morais, L. C. (2002), Comparison of sludges produced from two different recirculating aquaculture systems (RAS) for recycle disposal. Aquaculture, Netherlands, 502(1), 87-96. https://doi.org/10.1016/j.aquaculture.2018.11.060

Panase, P., Uppapong, S., Tuncharoen, S., Tanitson, J., Soontornprasit, K., \& Intawicha, P. (2018). Partial replacement of commercial fish meal with Amazon sailfin catfish Pterygoplichthys pardalis meal in diets for juvenile Mekong giant catfish Pangasianodon gigas. Aquaculture Reports, 12, 25-29. https://doi.org/10.1016/j.aqrep.2018.08.005

Pouil, S., Samsudin, R., Slembrouck, J., Sihabuddin, A., Sundari, G., Khazaidan, K., Kristanto, A. H., Pantjara, B., \& Caruso, D. (2019). Nutrients budgets in a small-scale freshwater fish pound system in Indonesia. Aquaculture, Netherlands, 504(1), 267-274. https://doi.org/10.1016/j.aquaculture.2019.01.067

Sabaouri, F., Gharabaghi, B., Sattar, A. M. A., \& Thompson, A. M., (2016) Event-based stormwater management pond runoff temperature model. Journal of Hydrology, 
Netherlands, 540(1), 306-316.

https://doi.org/10.1016/j.jhydrol.2016.06.017

Senff, P., Partelow, S., Indriana, L. F., Buhari, N., \& Kunzmann, A. (2018). Improving pond aquaculture production on Lombok, Indonesia. Aquaculture, Netherlands, 496(1), 64-73.

https://doi.org/10.1016/j.aquaculture.2018.07.027

Tran, N., Rodriguez, U.-P., Chan, C. Y., Phillips, M. J., Mohan, C. V., Henriksson, P. J. G., Koeshendrajana, S., Suria, S., \& Halla, S. (2017). Indonesian aquaculture futures: An analysis of fish supply and demand in Indonesia to 2030 and role of aquaculture using the AsiaFish model. Mar.
Policy. United Kingdom, 79(1), 25-32.

https://doi.org/10.1016/j.marpol.2017.02.002

Yamazaki, S., Resosudarmo, B. P., Girsang, W., \& Hoshino, E. (2018). Productivity, social capital and perceived environmental threats in small-island fisheries: insights from Indonesia. Ecological Economics, Netherlands, 152(1), 62-75.

https://doi.org/10.1016/j.ecolecon.2018.05.020

Yi, D., Reardon, T., \& Stringer, R. (2018). Shrimp aquaculture technology change in Indonesia: are small farmers included? Aquaculture. Netherlands, 493(1), 436-445. https://doi.org/10.1016/j.aquaculture.2016.11.003 